\title{
Sigla and Abbreviations
}

1. Greek manuscripts, editions, commentaries and translations of the Physics

$\alpha \quad$ Branch $\alpha$ represented by mss. $E \Psi$

A Alexander's Commentary as quoted by Simplicius

$\mathrm{A}^{\mathrm{s}} \quad$ Fragments of Alexander's Commentary (extant in the form of scholia), edited by M. Rashed, Alexandre d'Aphrodise: Commentaire perdu à la Physique d'Aristote, Berlin 2011

$\mathrm{A}^{\mathrm{m}} \quad$ Quotations of the Physics in Alexander's treatise Fì mabādi' alkull, edited by C. Genequand, Alexander of Aphrodisias, On the Cosmos, Leiden 2001

$\mathrm{A}^{\mathrm{r}} \quad$ Quotations of the Physics in Alexander's Radd'alā Ğàtīnūs fimā ța'ana bih̄̄ 'alā Arisțū fí anna kulla mā yatahararaku fa-inna-

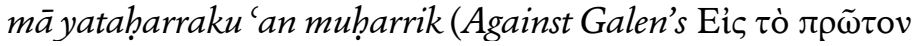

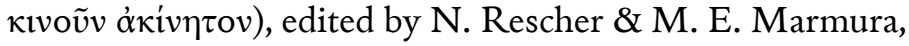
Islamabad 1965

$\beta \quad$ Branch $\beta$ represented by mss. $L N R$

b ms. Parisinus gr. 1859, ca. 1300

Bek Aristoteles, Opera. Ex rec. I. Bekkeri. Vol. 1. Berlin 1831

$\gamma$ Branch $\gamma$ represented by mss. F H I J $w$

Camotiana Johannes Baptista Camotius (Giovanni Battista Camozzi, ed.), Aristotelis De Physica Auscultatione, De Coelo, De Mundo [...]

Tomus II, apud Aldi Filios, Venetiis 1551

Car

$\delta$ Aristote, Physique. Texte établi et traduit par H. Carteron, ${ }^{3} 1961$ Branch $\delta$ represented by mss. $b e$

e ms. Vindobonensis phil. gr. 64, middle of the $15^{\text {th }} \mathrm{c}$.

$\mathrm{E}$ $E^{1} / E^{2}$ ms. Parisinus 1853, beginning/middle of the $10^{\text {th }} \mathrm{c}$.

$\mathrm{F}$ ms. Parisinus 1853, first/second hand

$\mathrm{H}$ ms. Laurentianus $87.7,14^{\text {th }} \mathrm{c}$. ms. Vaticanus gr. 1027, end of the $12^{\text {th }} /$ beginning of the $13^{\text {th }} \mathrm{c}$. $H$ as read by Bekker

$\mathrm{HaGa}$ Aristotle, Physica. Transl. R. P. Hardie, R. K. Gaye, Oxford 1930 
ms. Vaticanus gr. 241, $13^{\text {th }} \mathrm{c}$.

L

M

$\mathrm{N}$

$\Pi[($ praeter \#) $]$

P

$\mathrm{P}^{c}$

$\mathrm{P}^{\mathrm{l}}$

$\mathrm{Pp}^{\mathrm{p}}$

$\mathrm{Pa}$

Pacius

Pel

Pra

Q

$\mathrm{R}$

Ross

S

ms. Vindobonensis gr. $100,9^{\text {th }} \mathrm{c}$.

ms. Laurentianus $87.24,12^{\text {th }} \mathrm{c}$.

The Greek exemplar of the Latin translatio vetus of the Physics (by James of Venice, before ca. 1150) [not extant]

ms. Erlangen $\mathrm{A} 4,15^{\text {th }} \mathrm{c}$.

Parallels of the Physics in Aristotle's Metaphysics

ms. Vat. Barb. gr. 136, $12^{\text {th }}$ c.

Agreement of the manuscript branches $\beta, \gamma, \delta$ and mss. E and $\mathrm{K}$ [except for ms. \#]

Philoponus' Commentary (in general), Ioannis Philoponi in Aristotelis Physicorum libros tres priores commentaria. Ioannis Philoponi in Aristotelis Physicorum libros quinque posteriores commentaria. Edidit H. Vitelli, Berlin 1887-1888 (CAG XVI-XVII), cf. infra \$ 5: "Rashed 2016", "Rescigno".

Citation in Philoponus' Commentary

Lemma in Philoponus' Commentary

Paraphrase in Philoponus' Commentary

[Pseudo-]Michael Psellos, Kommentar zur Physik des Aristoteles, ed. L. Benakis, Athens 2008 [rather by George Pachymeres]

Iulius Pacius (Giulio Pace, ed.), Aristotelis Naturalis auscultationis libri VIII, Francoforti 1596

Aristote, Physique. Traduction et présentation par Pierre Pellegrin, Paris ${ }^{2} 2002$

Aristoteles, Acht Bücher Physik. Griechisch und deutsch hrsg. von Carl Prantl, Leipzig 1854

ms. Leidensis Voss. Q3, $12^{\text {th }} \mathrm{c}$.

ms. Vaticanus gr. $1025,13^{\text {th }} \mathrm{c}$.

Aristotle's Physics. Ed. with introduction and commentary, Oxford 1936

Simplicius' Commentary (in general), Simplicii in Aristotelis

Physicorum libros quattuor priores commentaria. Simplicii in

Aristotelis Physicorum libros quattuor posteriores commentaria.

Edidit H. Diels, Berlin 1882-1895 (CAG IX-X).

Citation in Simplicius' Commentary

Lemma in Simplicius' Commentary

Paraphrase in Simplicius' Commentary 
$\mathrm{T}$

W

Wag

WiCo

$\xi$

$\Psi$

$\Psi^{\Omega}$

$\Psi^{*}$
Themistii in Aristotelis Physica paraphrasis. Edidit H. Schenkl, Berlin 1900 (CAG V.2)

ms. Parisinus Suppl. gr. 643, $13^{\text {th }}$ c.

Aristoteles, Physikvorlesung. Übersetzt von H. Wagner, Darmstadt 1967

Aristotle, Physics. With an English translation by P. H. Wicksteed \& F. Cornford, London 1929

Greek readings reconstructed on the basis of marginal or interlinear readings in $\Phi$ (cf. below, $\$ 2$ ) explicitly labelled as variae lectiones; such var. lectiones may trace back to Ishāq ibn Hunayn's translation of $\gamma \rho \alpha \dot{\varphi} \varphi \varepsilon \tau \alpha 1$-notes in $\Psi$, or to another Greek ms. consulted by Ishạa ibn Hunayn, or to later collation notes based on another Arabic translation of the Physics (viz. a commentary) Ishāq ibn Ḥunayn's main Greek exemplar (probably $8^{\text {th }} /$ early $9^{\text {th }}$ c.) reconstructed on the basis of the Arabic text preserved in $\Phi$

Ishāq ibn Hunayn's Greek exemplar reconstructed on the basis of an Arabic text preserved defectively in $\Phi$, yet correctable by means of the indirect Arabic and/or Arabo-Latin tradition Ishāq ibn Hunayn's Greek exemplar reconstructed on the basis of an Arabic text emended with the help of the received Greek text or divined by the present editor due to a corruption in $\Phi$ and the whole indirect Arabic and Arabo-Latin tradition

2. Arabic manuscripts, readings and editions of the Physics and related commentaries

Ar.

Ishāa ibn Hunayn's Arabic interpretation reflecting a certain disparity between the Greek and Arabic texts without implying necessarily a Greek Vorlage different from the received Greek text (cf. below, \$4)

Bad Arisțūṭālīs, al-Ṭabī'a. Ed. 'Abdurraḥmān Badawī, 2 vols., Cairo 1384/1964-1385/1965

$c^{\text {ar }} \quad$ Copy of Ishāa ibn Hunayn's translation used by Gerard of Cremona for his Latin translation (= C), before 1180 [not extant]

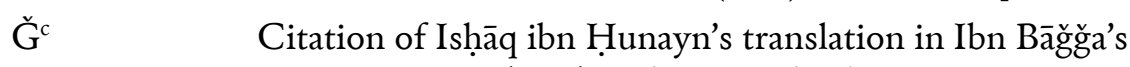
Commentary (Shurūḥāt al-Samāc al-țabīì , ed. Ma'n Ziyāda, Beirut 1398/1978) 


\begin{tabular}{|c|c|}
\hline $\mathrm{G}^{\mathrm{p}}$ & $\begin{array}{l}\text { Paraphrase of Ishāq ibn Hunayn's translation in Ibn Bāğğa's } \\
\text { Commentary }\end{array}$ \\
\hline & $\begin{array}{l}\text { Copy of Ishāq ibn Hunayn's translation that served as an ex- } \\
\text { emplar of } \theta^{1}, \theta^{2} \text {, etc. and was a third generation ancestor of } \Phi \text {, } \\
\text { ca. } 930 \text { [not extant }]\end{array}$ \\
\hline$\theta^{1}, \theta^{2} \ldots$ & $\begin{array}{l}\text { Copies of } \Theta \text { prepared (and annotated) by scholars of the Aris- } \\
\text { totelian school in Baghdad between ca. } 930 \text { and } 1000 \text { [not extant] }\end{array}$ \\
\hline $\mathrm{n}^{\mathrm{C}} \mathrm{Ad} \overline{\mathrm{1}}$ & Yahyā ibn 'Adī's comments on the Physics as edited in "Bad" \\
\hline n al-Tayyib & $\begin{array}{l}\text { Abū l-Farağ ibn al-Tayyib's comments on the Physics as edited } \\
\text { in "Bad" }\end{array}$ \\
\hline & $\begin{array}{l}\text { Common ancestor of } \mathrm{c}^{\mathrm{ar}}, \mathrm{vz} \mathrm{z}^{\mathrm{ar}} \text { (and other copies of Ishāq ibn } \\
\text { Hunayn's translation circulating in } 12^{\text {th }} \text { and } 13^{\text {th }} \text { c. Andalusia), } \\
\text { probably late } 11^{\text {th }} / \text { early } 12^{\text {th }} \text { c. [not extant] }\end{array}$ \\
\hline & $\begin{array}{l}\text { Copy of Ishāa ibn Hunayn's translation quoted in Ibn Rušd's } \\
\text { "Long Commentary", before ca. } 1185 \text { [not extant] }\end{array}$ \\
\hline & $\begin{array}{l}\text { Copy of Ishāa ibn Hunayn's translation prepared and/or } \\
\text { owned by Yahyā ibn 'Adì (d. 974) [not extant] }\end{array}$ \\
\hline & $\begin{array}{l}\text { ms. Leidensis or. 583, dated 540/1129-30, reproducing the } \\
\text { copy of Abū 1-Husayn al-Bașrī, dated 395/1004 }\end{array}$ \\
\hline$\Phi^{1} / \Phi^{2}$ & $\begin{array}{l}\text { Readings in } \Phi \text { ante correctionem and post correctionem (probably } \\
\text { by one and the same the hand) }\end{array}$ \\
\hline & $\begin{array}{l}\text { Common ancestor of } \Theta, \Sigma, \Phi \text { and ms. Escorial ár. 896, ca. } \\
920-930 \text { [not extant] }\end{array}$ \\
\hline
\end{tabular}

3. Latin manuscripts and witnesses of the Arabo-Latin translations of the Physics

C
$\mathrm{C}^{\mathrm{a}}$
$\mathrm{CP}^{\mathrm{p}}$
$\mathrm{C}^{\mathrm{v}}$

Arabo-Latin version by Gerard of Cremona (consensus of $\mathrm{C}^{\mathrm{a}}$, $\mathrm{C}^{\mathrm{p}}$ and $\mathrm{C}^{\mathrm{v}}$ ) based on the Arabic ms. $\mathrm{c}^{\mathrm{ar}}$, preserved in:

ms. Aosta, Biblioteca del Seminario Maggiore 71, late $12^{\text {th }} /$ early $13^{\text {th }} \mathrm{c}$.

ms. Parisinus lat. $16141,13^{\text {th }} \mathrm{c}$.

ms. Vindobonensis lat. $234 \mathrm{~A}, 13^{\text {th }} \mathrm{c}$.

Arabo-Latin version by Michael Scot as transmitted in the lemmata of Ibn Rušd's "Long Commentary", based on a descendant of $\mathrm{vz}^{\mathrm{ar}}$ (unpublished critical ed. by Horst Schmieja, Thomas Institute Cologne) 
Anonymous Arabo-Latin version (by Hermannus Alemannus?) of Book VIII, 265a27-b16 and 266b6-267b26, as transmitted in the lemmata of Ibn Rušd's "Long Commentary", based on a descendant of $\mathrm{vz}^{\text {ar }}$ (unpublished critical ed. by Horst Schmieja, Thomas Institute Cologne)

\author{
4. Abbreviations used in the apparatuses \\ acc. accusative \\ add. addition, added by \\ adnot. annotation(s), footnote(s) or commentary (by modern scholar[s]) \\ Alex. Alexander of Aphrodisias \\ App. 1 the first critical apparatus (recording Greek variant readings) \\ App. 2 the second critical apparatus (informing about the constitution \\ of the Arabic text) \\ App. 3 the third apparatus (dealing with scholia and annotations in $\Phi$ ) \\ c. cum; used together with \\ comm. commentary (both ancient Greek and Arabic comments in $\Phi$ ) \\ corr. correction, corrected by the scribe \\ $\gamma \rho$. " $\quad \rho^{\prime} \alpha \dot{\varphi} \varphi \tau \iota$ ", variant reading mentioned in one of the ancient \\ commentaries \\ del. deletion, deleted by erasure or crossing out \\ dittogr. dittography \\ err. typ. typographical error \\ exp. $\quad$ expunxit; deleted by use of superscript points by \\ fort. fortasse; perhaps \\ gen. genitive \\ gloss marginal or interlinear gloss or scholium next to Isḥāq ibn \\ Hunayn's translation in $\Phi$ \\ haplogr. haplography \\ i.l. infra lineam; below the line \\ i.m. in margine; in the margin \\ illeg. illegible \\ ind. indicating, indicated by
}


intell. Ar.

intell. $\mathrm{C} / \mathrm{V} / \mathrm{Z}$

interpol. interpr. Ar.

Indicates a disparity between the received Greek text and Isḥāq ibn Hunayn's translation which may originate from an elaboration or addition by Isḥaqq ibn Hunayn and cannot be attributed unambiguously to $\Psi$

$\begin{array}{ll}\text { intell. C/V/Z } & \begin{array}{l}\text { Indicates a disparity between the edited Arabic text and the transla- } \\ \text { tion by Gerard of Cremona/Michael Scot/Anonymous which may } \\ \text { originate from an elaboration or addition by the Latin translator } \\ \text { and cannot be attributed unambiguously to bis Arabic exemplar }\end{array} \\ \text { interpol. } & \begin{array}{l}\text { interpolation, interpolated by } \\ \text { interpr. Ar. }\end{array} \\ & \begin{array}{l}\text { Indicates a disparity between the received Greek text and the Ar. } \\ \text { translation caused by the fact that Ishāq ibn Hunayn's Greek } \\ \text { exemplar - although basically consistent with the received Greek } \\ \text { text (or one of its branches) - was crabbed, ambiguous (e.g. miss- } \\ \text { ing accents) or slightly damaged, thus requiring some interpreta- } \\ \text { tive decision }\end{array}\end{array}$

interpr. $\mathrm{C} / \mathrm{V} / \mathrm{Z}$ Indicates a disparity between the edited Arabic text and the translation by Gerard of Cremona/Michael Scot/Anonymous caused by the fact that an Arabic word - although basically consistent with $\Phi($ viz. $\Omega)$ - appeared in the latter's Arabic exemplar in an ambiguous way (e.g. missing diacritics) requiring some interpretative decision

inv. inverted, (two words) written in reverse order by

i'punxit Ar. Indicates a disparity between the received Greek text and Ishāq ibn Hunayn's translation caused by the latter's idiosyncratic parsing or punctuation of the Greek text without necessarily implying a problem or variant reading in $\Psi$

iter. iterated by

1 . line

lac. lacuna

leg. legendum; to be read

litt. litterae; letters

loc. locus; the place in question

marg. margin

non vert. Ar. Indicates the absence of an Arabic equivalent of a Greek word in Isḥa q ibn Hunayn's translation which does not necessarily imply its omission in $\Psi$, but may bave been caused otherwise 
non vert. $\mathrm{C} / \mathrm{V} / \mathrm{Z}$ Indicates the absence of a Latin equivalent of an Arabic word in the translation by Gerard of Cremona/Michael Scot/Anonymous which does not necessarily imply its omission in the translator's Arabic exemplar, but may have been caused otherwise

om. omitted by or not present in

om. hom. omitted due to homoioteleuton by

Philop. John Philoponus

propos. proposed by

ras. in rasura; written over an erasure by

s.l. supra lineam; above the line

s.p. sine punctatione; without diacritical points

S.r. sub radice; (listed) under the root

s.v. sub voce; (listed) under the word

scil. scilicet; i. e.

scr. scripsit; as read/modified by the modern editor

sec. secundum; according to

secl. secluded or bracketed by

sim. similar(ly)

Simpl. Simplicius

suppl. supplied by

Them. Themistius

tit. title, subheading

transl. translation(s), translated by transp. transposed to (the place indicated) by vid. v. ut videtur; as appearing in the manuscript vide; see

5. Modern works referred to in the apparatuses

Bonitz II/III Hermann Bonitz, Aristotelische Studien II-III. Wien 1863 [= Sitzungsberichte der phil.-bist. Classe der kaiserlichen Akademie der Wissenschaften XLI, Bd. 8, p. 379-434, XLII, Bd. 8, p. 25-109].

Denniston John Dewar Denniston, The Greek Particles. Second ed. revised by K. J. Dover. Oxford 1950, repr. London 1996. 
Diels

Dozy

Freytag

GALex I/II

Giannakis

Glossary

Gutas Theophr. Dimitri Gutas, Theophrastus On First Principles (known as his Metaphysics). Greek Text and Medieval Arabic Translation, Edited and Translated with Introduction, Commentaries and Glossaries, as Well as the Medieval Latin Translation, and with an Excursus on Graeco-Arabic Editorial Technique.

(Philosophia Antiqua; vol. 119), Leiden 2010.

Hayduck

Lane

Rashed

Rashed 2016

Hermann Diels, "Zur Textgeschichte der Aristotelischen Physik", Philosophische und historische Abhandlungen der Königlichen Akademie der Wissenschaften zu Berlin 1882, Abhandlung 1, Berlin 1883, p. 3-42. arabes. 2 vols., Leiden 1881, 3ème éd., Leiden 1967.

Georg Wilhelm Freytag, Lexicon Arabico-Latinum. 4 vols., Halle 1830-1837. ary of the Mediaval Translations from Greek into Arabic. Vol. I, second revised ed. by R. Arnzen, G. Endress, D. Gutas with the assistance of G. J. Moseley, Leiden 2020; Vol. II, ed. by G. Endress \& D. Gutas, Leiden 2017. St. Antony's College, 1992.

The Greek-Arabic and Arabic-Greek glossaries at the end of the present book.

Michael Hayduck, Bemerkungen zur Pbysik des Aristoteles, Greifswald 1871.

Edward William Lane, An Arabic-English Lexicon. 8 vols. London 1863-1893, repr. Beirut 1968.

Marwan Rashed, Alexandre d'Aphrodise, Commentaire perdu à la Pbysique d'Aristote (Livres IV-VIII). Les scholies byzantines. Édition, traduction et commentaire. (Commentaria in Aristotelem Graeca et Byzantina. Quellen und Studien; vol. 1.) Berlin 2011.

Marwan Rashed, "Fragments inconnus du commentaire à la Physique de Jean Philopon”, in M. Rashed, L'Héritage aristotélicien: Textes inédits de l'Antiquité. Nouvelle édition revue et augmentée. Paris 2016, p. 751-777. 
Rescigno Andrea Rescigno, "Nuovi frammenti del Commento di Filopono ai libri V-VIII della Fisica", Studia Graeco-arabica 7 (2017), p. 75-104.

Torstrik Adolf Torstrik, "Die authentica der Berliner ausgabe des Aristoteles", Philologus. Zeitschrift für das Klassische Altertum 12 (1857), p. 494-530.

Ullmann NE I/II Manfred Ullmann, Die Nikomachische Ethik des Aristoteles in arabischer Übersetzung. Teil 1: Wortschatz. Wiesbaden 2011; Teil 2: Überlieferung, Textkritik, Grammatik. Wiesbaden 2012.

WGAÜ (Suppl.) Manfred Ullmann, Wörterbuch zu den griechisch-arabischen Übersetzungen des 9. Jahrhunderts. Wiesbaden 2002; Supplement vols. 1-2. Wiesbaden 2006-2007.

WKAS Manfred Ullmann, Wörterbuch der Klassischen Arabischen Sprache. Herausgegeben durch die Deutsche Morgenländische Gesellschaft. Vol. I, vol. II in 4 parts, Wiesbaden 19702009. 
